\title{
Ben Ammi's Adaptation of Veganism in the Theology of the African Hebrew Israelites of Jerusalem
}

\author{
Michael T. Miller \\ Associate Research Fellow, Polish Institute of Advanced Studies, \\ Warsaw, Poland \\ Michael.Miller@nym.hush.com
}

\begin{abstract}
This article will look at the ideology of veganism in the AHIJ. Since the early 1970s their diet has been a core part of their ideology and of their message to the world. Acknowledging that a black/Jewish meat-free diet is far from the exclusive property of the group, let alone a new development on their part, I will argue that it is an expression of the syncretic "bricoleur" nature of Black Israelite thought (Dorman 2013), reflecting, drawing on, and transforming traditions existing in both African American and Jewish thought in and before the twentieth century - principally articulated as a concern for health in the former and a messianic return to the peaceful Edenic existence in the latter. However, Ben Ammi skillfully intertwines it into their theology by arguing that a return to the veganism of the Garden of Eden is part of the community's redemption of humanity from primordial sin and ultimate overcoming of the curse of death.
\end{abstract}

\section{Keywords}

Black Judaism - Hebrew Israelites - veganism - foodways - Israel - African American religion 


\section{Introduction}

The African Hebrew Israelites of Jerusalem (AHI) are a community of African American descent, who have lived in Israel since 1969. ${ }^{1}$ They are part of the broader "Hebrew Israelite" movement which holds that African Americans are authentic descendants of the biblical Israelites. ${ }^{2}$ As a result they stand with one foot in the African American world, and one in the Jewish. Other than their exodus from America, another factor that marks them out from other denominations is their veganism, which is a core part of their theology and lifestyle: they pre-empted the currently fashionable vegan diet, adopting it as an integral part of their lifestyle since the early 1970s. ${ }^{3}$ Their community of c. 3,00o people in Israel is entirely vegan and they make diet a critical element of their outreach as part of what Markowitz and Avieli have termed "culinary redemption", ${ }^{4}$ opening the first vegan outlet in Israel in 1984 (Eternity, a kiosk on Tel Aviv's Ben Yehuda Street), following their Soul Vegetarian restaurants opened in Atlanta in 1979 and Chicago in 1982. Previous research has discussed the importance of their diet in their lifestyle, but yet to be examined are the sources and points of influence - that is to say, how the community adapted and transformed previous theorising about and adoption of plant-based diets. This paper will look at how their veganism relates to and draws upon traditions of plant-based eating in both African American (AA) and Jewish thought, with the aim of showing to what extent and in what way these two influences combine in their worldview. ${ }^{5}$ In particular, I will examine the AH IJ's approach

1 See Hare, Hebrew Israelite Community; Könighofer, Dynamic Diaspora; Jackson, Thin Description; Baer/Singer, African American Religion. The best depiction of their beginnings and their more recent evolution are given in Singer, Symbolic Identity Formation and Michaeli, Another Exodus respectively.

2 See Landing, Black Judaism; Dorman, Chosen People; Key, Towards a Typology; Miller, Black $\operatorname{Judaism}(s)$.

3 Vegetarianism is not common among Hebrew Israelite groups; the only prior reference I can find is to Rabbi Naphtali Israel of Chicago in 1965; see Berger, BlackJews, p. 192. One AHIJ member told Singer (Saints, p. 72) that "some" groups of Chicago Hebrew Israelites were vegetarian, whereas "some just kept kosher", but did not provide more detail.

4 Avieli/Markowitz, Slavery Food.

5 Both the Jewish and Afro-American communities exhibit higher than average levels of plantbased eating. $8 \%$ of Afro-Americans are vegetarian or vegan (Vegetarian Resource Group, How Many Adult Vegetarians), compared with $3 \%$ of the general population (Funk/Kennedy, New Food Fights). For the issues involved here see Harper, Sista Vegan. There are no available figures for Jewish dietary habits, but in 2017 seventy-five rabbis from across the religious spectrum signed a statement urging all Jews to adopt a plant-based diet (Chandler \& Cohan, Jewish Vegan), and Israel currently boasts the highest number of vegans per capita at $5 \%$ (and second to India for proportion of vegetarians, at 13\%, Greenstone/Shmuel, Linguistic Appraisal). 
to diet as expressed in the thought of the AHIJ's spiritual leader and theologian Ben Ammi (1939-2014), before comparing this with those of contemporaries and precursors in AA and Jewish thought - Alvenia Fulton, Dick Gregory, and the Nation of Islam's (NOI) Elijah Muhammad, and Rabbi Abraham Isaac Kook respectively. Much has already been written on the dietary views of Muhammad, and the rabbinic views on meat-eating, but I will highlight certain aspects of these in order to show how the AHIJ's foodways relate to, and transform, each of them.

This analysis will help to demonstrate how the AHIJ continue to combine many sources and rationalities in their outlook and practice. The combination of biblical interpretation which is very much in line with that of the rabbis and contemporary Jewish ethical thought, and health-consciousness which draws from the mid-2oth century African American counterculture (including the religious counterculture of the NOI) illustrates what Dorman has termed the "polycultural bricoleur" nature of the Black Israelite movement, that the generations have drawn upon many different streams of tradition that were available to them in the Americas in order to construct a functionally new religious movement. ${ }^{6}$ It will also show that there exists a deep similarity between the nature and the motivations of the NOI's dietary reforms and those of the AHIJ.

My evidence will be mostly textual but also include some material from interviews with community members. These semi-structured interviews were conducted over Zoom during the summer of 2020 , with six long-term members of the community who were selected by my contacts because of their involvement in the community's food services and industry.

\section{The Vegan Ideology of the AHIJ}

One narrative told by the community locates the shift to veganism at the very outset of their story. Having left America in 1967 for the initial destination of Liberia and with the aim of living by Mosaic law, they encountered difficulty when preparing for the second year's Pesach (Passover) festival: It is commanded that a lamb must be slaughtered, but no lamb could be located. Eventually on the eve of the festival, they found someone willing to sell them a goat (at a much-inflated price), which was deemed an acceptable substitute. But when they came to retrieve the goat on the day of the festival, they found it had strangled itself as it pulled on the ropes they used to tie it with - thereby rendering itself unclean (an improperly killed animal cannot be a sacrifice). The community were distraught as they wondered what this act of divine

6 Dorman, Chosen People. 
disapproval meant and how it could be overcome - after some contemplation, one of the founders and leaders, Ben Ammi, returned to tell the people that this was in fact a sign that God no longer desired animal sacrifices for they were already sacrificing themselves. This message was one that shifted the community from terror and confusion to realising they had received a new revelation, a sure sign that God was with them, and cemented Ben Ammi as leader of the group. In one of the community's first publications, Gabriel HaGadol recounts this and links it with their later decision to forsake flesh as food. ${ }^{7}$ However, other members have denied the singular importance of this event, casting it as only grounds for further scriptural study, which was what ultimately led them to the decision. ${ }^{8}$

It is not entirely clear when they as a community took on the new diet, ${ }^{9}$ but it seems to have been in the first two years of the 1970s: A 1970 article in Israel Magazine states that they are vegetarian, ${ }^{10}$ but the first self-declaration I can find is a brief and confrontational interview with Ben Ammi in October 1971, where he states as an aside that "[w]e do not eat meat."11 However, reports from Liberia in 1968 and 1969 have members selling ice cream, hamburgers, and soul chicken, ${ }^{12}$ while another notes only that "many are vegetarian". ${ }^{13}$ One member told a reporter in 1969 that "most" were vegetarian ${ }^{14}$ and members have stated that it was not until the early 1970 s that diet became consciously regulated..$^{15}$ The most likely explanation is that given in a 1979 article in the Jerusalem Post: While they were "quasi-vegetarians" in Liberia, it was only in 1973 that Ben Ammi and Shaleak Ben Yehuda centralised their authority over the different groupings (both physical and ideological), and it was then that dietary practice, among other things, became doctrinal rather than a matter of individual choice. ${ }^{16}$ This seems accurate, as various sources suggest that Ammi and Ben

HaGadol, Impregnable People, pp. 213-217; See Singer, Symbolic Identity Formation, p. 65 et seq.; Avieli/Markowitz, Slavery Food, pp. 214-216; Jackson, Thin Description, p. 316 et seq. A short document circulated by the community in 1973 makes no connection of the Passover event with diet:Journey.

9 Markowitz/Avieli, Slavery Food, present several illuminating interviews with members regarding this.

10 Wigoder, America's Black Jews in Israel, p. 36.

11 Rosenblum, The Dibbuk in Dimona, p. 27.

12 Emerson, U.S. Negroes Content; A.P., Judaist Negroes Drift.

13 Ma'ariv, Ben-Ami and Hezekiahu Came From Liberia.

14 Gibeon, From Slavery.

15 Avieli/Markowitz, Slavery Food, p. 9.

16 Jerusalem Post, Cult's Critics Charge Secrecy, Strictness, and Brainwashing. Corroborating this, I have been told they were all vegan by the time of one member's arrival in 1973 . Singer puts the decisive moment at 24th October 1972, when Ben Ammi called a meeting 
Yehuda were strong advocates of a plant-based diet from the early days of the movement. ${ }^{17}$ From this point, the community quickly became entirely vegan and were producing their own almond milk and tofu by the mid-197os.

Since the 1980s, the community's diet has been one of their most remarkedupon qualities - second only to their African American origin. The diet is part of a committed holistic lifestyle wherein earthly life and the body that allows it are of paramount importance, expressed in a regime of thrice weekly exercise, massages, frequent days and weeks of no-salt or sugar, abstinence from all narcotic substances, regular raw food and weekly fasts (every Shabbat). ${ }^{18}$ This approach has provided numerous benefits including, according to the community, the virtual elimination of lifestyle diseases (cancer, heart disease, diabetes, etc.) which plague AAs. ${ }^{19}$

Ben Ammi has explained the significance of the vegan diet at length, drawing on both biblical and scientific sources, arguing that an "Edenic diet" of plants is best suited to human beings as they were designed by God. This notion of an "Edenic diet" alludes to the first chapter of Genesis, wherein Adam and Eve are told "I give you every seed-bearing plant that is upon all the earth, and every tree that has seed-bearing fruit; they shall be yours for food." (Gen. 1:29) No mention is here made of eating animals or anything other than plants; in fact, it is not until God instructs Noah, post-flood, how he and his offspring should conduct themselves, that meat-eating is officially sanctioned. Although Ammi does not explicitly cite this passage, it is clearly in his mind when he writes that " $[\mathrm{t}] \mathrm{o}$ seek and serve a Living God, a man must maintain a living body and mind, fed with the life-giving 'live' foods: the fresh fruit, green vegetables and 'herbs of the field' diet which God gave to original man."20 The biblical passage is often quoted by other community members in relation to their diet. ${ }^{21}$

In his typical style of close analysis and unpacking of scripture in the light of external authorities which serve to justify his insights, Ammi offers further explanation of why such a diet is suited to humanity: in Genesis 1 Man (Adam) was taken from the earth (Adamah). Ammi claims that modern science has

at a hilltop and told of a new revelation regarding the community's "divine purpose and mission," and created the leadership structure which persists to this day: Singer, Identity Formation, p. 68.

17 E.g. Whitfield, Night to Sunlight; Avieli/Markowitz, Slavery Food; Ammi recounts his own adoption of vegetarianism in America in Ammi, Messiah, p. 135.

18 See Hare/Yehuda/Israel, Emphasizing the Holy.

19 It is difficult to confirm this but see Elkayam, Food for Peace and Jackson, Thin Description, p. 184 for details of scientific health studies into the community.

20 Ammi, God, the Black Man \& Truth, p. 44.

21 Yadah Baht Israel cites this passage as header to the Dietary Habits section of The Holistic Lifestyle, p. 11 . 
shown that precisely the same minerals are present in the soil as are found in human bodies. ${ }^{22}$ Therefore, in order to replenish our bodies, we need only consume the direct product of the soil: plants constitute the perfect delivery system for nutrients otherwise locked in indigestible earth. In contrast, "[t]he minerals absorbed through the consumption of animal flesh have been predigested by those animals and are [...] grossly inferior."23

Ammi consistently valorises plant sources over animal sources as beneficial, nutritious, and correct. In his logic, "[t]he blood and organs of the flesh of dead animals can only produce its counterpart [i.e., death]. The calf livers, dog cutlets, and bear paws you eat today will also be your blood, organs and thoughts of tomorrow."24 Plants are a part of harmonious living not just nutritionally, but also because farming and harvesting them connects humans to the life cycles of the planet. ${ }^{25}$ Consuming animals has the opposite effect:

The bond between the soil, the food and the soul should not be broken by the consumption of animal flesh. If we are to ascend into the higher realms of the living/life-experience promised by Yah through His inspired prophets, we must give our mind, body and soul a healthy chance to evolve through a corresponding nutritional/dietary standard. ${ }^{26}$

Therefore:

[Veganism is] us going back to live in harmony with the will of the creator, to move from the transient to the eternal. And I am simply saying to our people that animal consumption has nothing to do with your beginnings but it does have to do with your endings, because when you consume animal flesh you move from the eternal to the transient. So I am a vegan, I am a vegan because I am consuming from the source of my creation, the soil from which I was taken, from that same soil I receive all of my nutrition. ${ }^{27}$

Ammi's rejection of animal flesh is predicated largely without reference to the lives of animals, but rather with reference to the effects of their consumption

22 Enumerated as either 102 (Ammi, Physical Immortality, p. 62), or 112 (Ammi, The Global Crisis).

23 Ammi, Physical Immortality, p. 61.

24 Ammi, God, the Black Man and Truth, p. 45.

25 Ammi, Everlasting Life, pp. 141-144.

26 Ammi, Physical Immortality, p. 59.

27 Ammi, The Global Crisis. 
upon humans. As he expounds that "all master teachers know that veganism once was the proper diet of humanity", he explains this and argues for it solely with reference to nutrition: even though "steak is actually a portion of a dead animal that has begun to decay," it is because "[a]ny nutrients that may have been living in the animal begin to dissipate the longer the cut of meat sits" that this is a problem; it is the logical consequence that consuming death leads to death which engenders the conclusion that meat should be avoided. ${ }^{28}$

In this, as in all his other discussions of diet, there is no mention of animals as subjects who might bear rights. Ben Ammi is not without concern for animal welfare, as evidenced when he discusses the plight of chickens wrenched from their natural cycle in order to maximise egg production, and that "dogs, cats, birds and fish were naturally equipped by God to thrive outdoors, not indoors. Animals locked in the house and in zoos can be equated to man being imprisoned in the worst kind of dungeon or maximum security prison."29 It is curious that he never relates this concern to diet; it may be that he simply thought it was obvious, although he is usually very careful to spell out the reasons and implications he perceives in order to leave the reader in no doubt about his agenda. In fact, his concern for global ecology is more often raised than his concern for the suffering of animals. ${ }^{30}$ In part, we may explain this as Ben Ammi's concern for the system over its constituents - his anthropoholistic outlook, with humanity at the centre, means that he is far more concerned about the extinction of species than the death of individual animals; after all, many humans are dying terrible deaths but he is concerned with the future of the human race, not of individuals. Even in his express concern for his own people, it is the Israelites (African Americans) as a people he cares about, over and above any members of that group. ${ }^{31}$ This we might easily relate to his grounding in the Hebrew Bible which is overwhelmingly concerned with the national fate of the Israelites.

While Ben Ammi talks often about the health aspects of veganism, veganism alone is no cure; it is necessary but not sufficient, must be taken as part

28 Ammi, Messiah, p. 7o.

29 Ammi, God, the Black Man \& Truth, p. 213. There is also a brief mention of societies founded to prevent animal cruelty as doing their part of the work showing us the way away from "the life-destroying, perverted patterns that have become the norm today," Ammi, Messiah, p. 7 o.

$30 \quad$ E.g. Ammi, God, the Black Man \& Truth, p. 184.

31 In 1984 he seems to have shrugged off the death of fifteen of the community's children from malnutrition as unfortunate collateral in the pursuit of a grand objective: "Just like there are those experimenting with the atomic age we're experimenting with the age of health, the age of love, the age of sharing. But we're paying the price first for the people of Israel, and afterwards for all men." Elliott, Newsview, p. 17. 
of a righteous lifestyle that includes other physical self-care actions as well as one's thoughts, relations, and the ideas that one imbibes. Everything in individual lives must be oriented towards God, and through this draw sustenance from the Divine, life-giving, Truth. ${ }^{32}$ The incorporation of God in order to get the full results from healthy eating is as essential as vitamin $\mathrm{C}$ is for absorbing iron: "there is a bond between what you eat and the state of mind when you are eating. All of your inner organs are calibrated to respond to a certain code of consciousness. Just to be a vegan is superficial. It is the spirit of the vegan that is vital in releasing the relative response." ${ }^{33}$ Even eliminating meat from one's diet only to replace it with meat substitutes can be just as harmful - if one subconsciously craves flesh and experiences the substitute as it, "you're still eating meat; it's just made of something else!"34 - because the body is working as if it were processing meat, the harm is the same.

Health is a fundamental component of the community's message. As John Jackson notes, the "health message is central to the community's larger cosmological and spiritual goals, but it is also somewhat detachable from those concerns. Saints consider their health mission one of the Kingdom's most important, practical, and immediate interventions." ${ }^{35}$ If the world cannot be saved outright, then preventing people from killing themselves is a good start. However, it is not health itself which is presented as desideratum in Ammi's theology, but rather righteousness. Ammi consistently argues that the reason for poor health is humanity's unrighteousness, because of our rebellious refusal to follow the guidelines given by God for best-practice living. We are killing ourselves and the world by engaging in practices we have been warned against. One of the crucial consequences of veganism as an aspect of righteousness is that of immortality: ${ }^{36}$ According to Genesis 3:19, death was a punishment imposed upon Adam and Eve, one not originally intended and not necessary for humanity; according to Ammi, once humanity returns to righteous obedience to God, then the punishment will be lifted. Then, the curse of death will disappear as our bodies begin to function as they were intended, perpetually

\footnotetext{
32 Ammi, Everlasting Life, pp. 43, 132 ff.

33 Ammi, Physical Immortality, p. 77. See Shaleak Ben Yehuda's comments in Lounds, Israel's Black Hebrews, p. 59.

34 Ammi, Relativity, p. 53. Meat substitutes such as tofu and seitan are an integral part of the community's restaurant menus, presumably acceptable there because the community have the right mindset and know how to eat it.

35 Jackson, Thin Description, p. 216 et seq.

36 Ammi, Everlasting Life; Ammi, Physical Immortality. See Jackson, Thin Description, p. 136.
} 
regenerating themselves without decay. ${ }^{37}$ The fact that this lifestyle is one that causes no harm to other living creatures is not separable from the fact that it also causes no harm to us: this is the way that the holistically designed world we live in works, and the diffusion of negative effects is a necessary part of the entry of unrighteousness into this world: our actions would never affect only ourselves. Ben Ammi's system is one based on a binary conception of lifedeath; worshipping the source of life leads to life, anything else leads away from life and toward death; in his opinion it is surely not by accident that a lifestyle that requires the killing of others ultimately kills oneself. Therefore, returning to plant-based eating will aid not only ourselves but all of creation: "This dietary formula (biological nutrition from the soil) [...] will guide the world's inhabitants in a new direction, away from hospitals and pharmaceuticals while playing a major role in restoring the planet's ecological balance."38

These explanations of Ben Ammi are mostly shared by the community. Yadah Baht Israel's description of their diet talks only of its role "[a]s part of their system of preventive health care,"39 and Markowitz \& Avieli report that they "have never heard a Hebrew mentioning animal suffering (or animal rights) as the reason for their veganism." ${ }^{40}$ In my conversations with members on this topic, some have mentioned compassion for animals among the reasons for the community's veganism, although this was always third after the prime motives of personal health and living in harmony with the world. One member claimed that the health and the ethical were "hand in glove" and went on to say that the crucial thing was conceiving dominion as different from domination - that is, the giving of dominion to humans was a duty of care, not one of freedom to abuse. The establishment of the community's four subsequent restaurants in Tel Aviv was apparently intended to spread the idea of eating healthily and preserving one's life to Israelis, as AHIJ's Soul Veg restaurants were spreading that message in the USA. The single notable exception to this may be Shaleak Ben Yehuda, who in one early interview presented the principal reason for their vegetarianism as the avoidance of taking life. ${ }^{41}$

37 The death of Ben Ammi in December 2014 has not negated this philosophy, although members have subtly revised their statements such that immortality is an end-goal, not necessarily one that will be attained immediately.

38 Ammi, Physical Immortality, p. 26.

39 Baht Israel, The Holistic Lifestyle, p. 13.

40 Markowitz/Avieli, Food for the Body and Soul, p. 12.

41 Lounds, Israel's Black Hebrews, p. 6o. 
It would not be possible to characterise Judaism as a vegetarian or vegan religion; meat is central to much of Jewish life, culture and ritual. However, the idea of vegetarianism has for a long time been a part of Judaism, and in the last 100 years this idea has increasingly become a reality for many Jews.

In common rabbinic interpretation there are two biblical passages which express this: the non-violent Eden of Gen. 1:29 and the post-violence messianic age where "the wolf and the lamb shall graze together, and the lion shall eat straw like the ox, and the serpent's food shall be earth. In all My sacred mount nothing evil or vile shall be done," (Is. 65:25) seem to temporally frame the corrupt contemporary state of humanity with a vegan utopia free from death and suffering for all sentient beings. There is no unanimous agreement but the vegetarianism of Eden is confirmed by a number of early rabbis ${ }^{42}$ and supported by the pivotal medieval commentator Rashi ${ }^{43}$ along with most other commentators; ${ }^{44}$ similarly, several commentators have supported the notion of a meat-free messianic age, ${ }^{45}$ reaching its zenith in the 20 th century when Rabbi Abraham Isaac Kook wrote powerfully on the time when the right of animals to live good lives and not be merely objects for human use would be realised. ${ }^{46}$

However, it has commonly been accepted, at least until recent decades, that the current age is one where the consumption of animals is permitted, even expected. In this case, extensive restrictions apply to the use, treatment, and killing of animals: The rabbinic formulation tza'ar ba'alei chayim, ${ }^{47}$ the "suffering of living creatures" covers a number of biblical precepts: Extrapolating from frequent commands to care for domestic animals, allow them to pursue their nature and interests, not oppress them, harm them or allow them to come to harm without good need, and even to allow them, as a part of the community of Israel, to rest during Sabbath; and with strident restrictions on the killing and consumption of their flesh (along with an even greater restriction

42 b.San. 59b; Gen Rabbah 34:13.

43 Commentary to Gen. 1:29; 9:3.

44 Schwarz, Vegetarianism, p. 1.

45 Isaac Abravanel is one who interpreted Isaiah's messianic peace as literal, that "in the messianic age things will return to their original state, predatory beasts will not hunt and domestic animals will not be eaten." This lack of meat eating will lead to a lack of cruelty even in lions. Saadia Gaon, too (Beliefs and Opinions 8.8) and Nahmanides (on Lev. 27:6) do not say explicitly that we will not eat meat but acknowledge that the messianic age is one of peace between and among humans and animals.

46 Kook, Vision.

47 See esp. b.Baba Metzia $32 b$. 
on human use of wild animals), the rabbis argued that preventing unnecessary animal suffering was essential.

The key concept, of course, is "unnecessary". Although the killing of animals was heavily restricted, and the shekhita (ritual slaughter) rules were understood by the rabbis to be principally for the avoidance of suffering, it was not viewed as in any way unjust at the present time. Conversely, compassion for animals was necessary despite the fact that we use them for food. The total ban on hunting for sport evidences such concern. ${ }^{48}$

So, while God relents and allows Noah and his children to eat meat after the flood, animals are never represented as simple bodies devoid of feeling; they may be less sophisticated than humans but they still can suffer and their suffering should be minimised where possible. No-one could deny that the Torah allows eating animals, but the restrictions put upon it and the way it is often talked about - disparagingly referred to as "the flesh of lust" - seem to some to offer a subtle rebuke of the practice. ${ }^{49}$ Several rabbis read Deuteronomy's concession that the Israelites may eat meat when they "have the urge" as meaning that meat should be eaten only when one feels an undeniable urge to do so. ${ }^{50}$ In this case, the practice is one that has been allowed not because it is good but because it is the lesser of two evils: God has realised that humans have a need to kill, and it is better that we kill animals than each other; but God provides strict rules and criteria for when and how such killing must be carried out, in order that we might begin to realise for ourselves that all life is holy and should be respected. This last point is the view of Rav Kook, who argued for an evolutionary perspective, that as humans (and specifically Jews) take the Law seriously and imbibe its lessons, we will begin to perceive the motive behind it and rise, of our own free will, to a higher level of ethical conduct - one which is too refined to command from the outset and which, if such concern

48 "I am amazed at the very concept [...] we never find such a thing in the Torah other than Nimrod or Esau (both hunters, both infamously wicked), and this is not the way of the children of Abraham, Isaac, and Jacob." R. Yehezqel Landau (cited in Cohen, Vegetarianism, p. 51).

49 "When [...] you say, 'I shall eat some meat,' for you have the urge to eat meat, you may eat meat whenever you wish." Deut. 12:20. The word translated as urge here, ta'avah, could equally be translated as lust. Schwarz, Jewish Vegetarianism, p. 10, argues that this is in direct contrast to the very positive associations made with non-flesh food; special blessings are commanded for cake, bread, wine, nuts, fruits, but for meat the default one is used, the same as for water. The beautiful Land of Israel is described as one "of wheat and barley, of vines and fig trees and pomegranates; a land of olive trees and honey; a land wherein you shall eat bread without scarceness" without any mention of meat (Deut. 8:7-10).

$5^{\circ} \quad$ b.Hullin $84 a$. 
for animals were to become an aggressive moralising prior to the extension of such concern to all humans, would lead to chaos: ${ }^{51}$

[T] he supreme vision, 'the wolf also shall dwell with the lamb' (Is. 11:6) is not a parable, but [should be taken] literally. Yet, it is a futile hallucination to introduce mercy to animals prematurely, while human blood is being spilled like water for nothing. We look disdainfully at animal welfare societies of sanctimonious anti-Semites who pity dogs, pigs and wolves, while being unconcerned about the fate of an oppressed nation [...]. These [values], which are pointless and even harmful nowadays, will become desirable and praiseworthy in the generations to come. An hour will arrive when humankind will acknowledge its calling to administer justice [...]. The sciences of physiology and psychology will assist humanity in reaching out to the beasts and in teaching them how to subsist without predation. ${ }^{52}$

The consequences for the human are also part of the Jewish ambivalence towards eating meat. Regarding the consequences for human health, Shemesh concludes, "the dominant thread among the Talmudic sages and commentators is that meat is beneficial if not indeed essential for health." ${ }^{\prime 3}$ This fact stands despite the frequent subtle condemnation of the act on ethical grounds. However, as may be expected today when the negative health consequences of animal products are widely discussed, the former Chief Rabbi of Ireland David Rosen is more emphatic: "As it is halachically prohibited to harm oneself and as healthy, nutritious vegetarian alternatives are easily available, meat consumption has become halachically unjustifiable." 54 On top of ethical responsibility towards animals and human health, there is one more element in the rabbinic literature: the consequences for human nature. The ability of humans to kill animals is seen as something which may too easily spill over into an ability to harm humans: ${ }^{55}$ Nachmanides writes,

$5^{1} \quad$ Kook, On Zionism, p. 34.

52 Kook, On Zionism, p. 34. Following the translation of Barilan, p. 9 o.

53 Shemesh, Vegetarian Ideology, p. 159.

54 Rosen, Vegetarianism, p. 54.

55 See Shemesh, p. 158. Krinsky, Relevant and Irrelevant Distinctions, argues that it is the moral effect upon the consumer which is the major concern, although it is not always obvious that when the sources foreground the "cruelty" involved in eating meat, that it is the effects upon the protagonist of this cruelty which is more important than the effects upon its victim. 
$[\mathrm{T}]$ he reason for the prohibition is to teach us the trait of compassion and that we should not be cruel, for cruelty proliferates in man's soul as it is known that butchers, those who slaughter large oxen and asses, are men of blood; they that slaughter are extremely cruel. It is on account of this that the rabbis have said 'the worthiest of butchers is Amalek's partner [i.e. evil].56

Likewise, Abravanel: "[M]eat is not an essential food, but is rather a matter of gluttony, filling the belly, and an overwhelming craving. In addition, meat generates maleficent and cruel blood in human beings". ${ }^{57}$ This idea that consuming meat inculcates barbarity is in contrast to Kook's claim that it sublimates bloodlust, but even Kook claims that the ban on pig meat was a preventative measure aimed at stopping pig farming, a practice which leads to unusually close human-animal relations and therefore the importing of animal barbarity into human societies.

These traditions have led, in the last 70 years, to a profound concern in the Jewish world with animal welfare. From the second half of the 2oth century onwards, individuals and even prominent rabbis have argued that vegetarianism is not just compatible with Judaism, but, at least in the modern world, required. The reasoning is not animal rights alone, but embraces a complex network of issues, including global warming, health, the environmental effects of animal agriculture, and the best use of grain and (increasingly scarce) water resources. However, the central concern is ethical: animals are not ours to use and abuse as we wish, but have souls and are subjects in their own right; if we interact with them in any way, we have a responsibility towards them. This perspective is clearly grounded in the biblical and rabbinic texts. The present upswing in concern is seen quite potently in the state of Israel, as already mentioned, where plant-based diets are embraced by both secular and religious Jews, for generally similar reasoning - principally ethics, secondly health and the environment.

Throughout the Jewish discussion of animals and the eating thereof, two factors are remarkable. The first is that the emphasis is overwhelmingly on ethics: the prime motivating factor is whether killing animals is ethical or not. Animals are conceived as subjects who have feelings, and therefore have certain rights that we must respect. The second is that, despite this, almost every commentator prior to the 2oth century did not forsake meat. Even Rav Kook

$5^{6} \quad$ Commentary to b.Kidd.82a.

57 Commentary on Exod. 16:4. 
consumed animal flesh. ${ }^{58}$ This is explained by the conviction that only the messianic age would see an end to such practices, and the messiah's arrival was in God's hands alone.

We have seen that, like the rabbis, Ben Ammi depends upon Gen. 1:29, despite never citing it explicitly. Likewise, he never cites Is. 11 or 65; this is once again curious, as it seems to form a large part of the backdrop to his own project: The return to the peaceful "Edenic diet" at this point in history is integral to Ammi's theology, because the descendants of the Israelites were now making their return to Eden (Africa) ${ }^{59}$ after 400 years in slavery (in America, the new Egypt predicted in Deut. 28). Ammi sees himself as the one foretold in Dan. 2:44-5 who would establish the eternal Kingdom of God, returning the Israelites to their God and His ways of righteousness, and tracing the steps of humanity back to undo Adam and Eve's sin of disobedience which has conditioned humanity's fallen era. ${ }^{60}$ The cover of his Imitation of Life even features a lamb and lion collaged as if lying together.

Ben Ammi does not mention negative psychological or moral effects of eating flesh, though one member has noted that returning to a plant-based diet might help to "get rid of the anger in the world." ${ }^{11}$ Similarly, one member who I interviewed with regard to the community's veganism asserted that their diet was only one element of a broader valuing of life and de-emphasising of physical strength and domination; it was ultimately about inculcating a broader peaceful and respectful approach to living.

Some members told me that the community's veganism had effected the prevalence of veganism in Israel; however, others told me that the real beginning was when American animal rights activist Gary Yourofsky visited Israel to give his lectures (the same is often stated by Jewish Israelis), ${ }^{62}$ after a YouTube video of his lecture at Georgia Tech with added Hebrew subtitles gained viral status. The nature of Israeli veganism, which appears to most frequently be tied to animal rights concerns, would support this assertion. ${ }^{63}$

Ben Ammi and the AHIJ have relied on the same texts as the rabbis, and interpreted them in very similar ways; however, there is no indication that rabbinic or contemporary Jewish thought influenced them. The differences in

$5^{8}$ There is some debate about his own opinion of contemporary vegetarianism. See Schwarz/Sears, Vegetarian Teachings, p. 248 et seq.

59 Israel is considered Northeast Africa; see Markowitz, Israel as Africa.

6o See Elkayam, Food for Peace. On Ammi's theology generally see Miller, Theology of Marginalisation.

61 Avieli/Markowitz, Slavery Food, p. 12.

62 Reuters, Israel: A Mecca for Vegans.

63 Weiss, No Chickens in Suicide Vests. 
motive and articulation support this conclusion, as does the posterior development of Israeli veganism. At the same time, the evidence suggests that the AH IJ were not initiators of Israeli veganism, although they were forerunners and have been able to support and assist the growing vegan public, especially with the commodities their factories produce.

\section{Vegan/Vegetarianism in African-American Tradition}

For many in 1960s USA, diet was a space of experimentation and deconstruction of received norms; the food we eat is part of the embedding of the individual within a cultural and political frame. Furthermore, the discipline required to commit to a radical new diet carries with it a new sense of self-control and agency; as Belasco writes, "[u]nlike attending, for example, a protest rally, altering one's diet was an ongoing endeavour, requiring a thrice-daily renewal of resolution. Each meal became, moreover, a consciousness-raising session [...]. To alter one's patterns of eating was, in a sense, to alter one's state of being." ${ }^{\prime 4}$ The link between what individuals ingest and how that affects or purifies their bodies, their state of mind, and the political state of society was an obvious one for many; diet was not a personal matter but had grander ramifications, and could be employed as a tool in changing the world.

From the same milieu of Black 196os Chicago that birthed the AHIJ, there are three notable figures who, to some extent, adopted and promoted a plantbased diet, linking it specifically with the plight of AAs: The early health-food pioneer Alvenia Fulton, comedian and civil rights activist Dick Gregory, and the second, most formative, leader of the Nation of Islam, Elijah Muhammad. ${ }^{65}$ Gregory recounts his realisation in 1965, apparently from contemplation of Martin Luther King's philosophy of non-violence, that "the killing of animals for food was both immoral and unnatural".66 This ethical imperative concerning animals stayed with him until his death in 2007 and was not limited to dietary matters - as evidenced by his involvement with PETA and concern for circus animals. ${ }^{67}$ However, it was his 1967 meeting with Dr Alvenia Fulton which led him into understanding (and practising) a health-conscious approach to plant-based eating. Fulton had opened the first health food store/vegetarian

\footnotetext{
64 Belasco, Appetite for Change, p. 34.

65 Witt believes there is a line of influence from Muhammad to Gregory regarding diet: Black Hunger, p. 133 et seq.

66 Gregory, Dick Gregory's Natural Diet for Folks Who Eat, p. 16; See Gregory, Callus on My Soul, p. 111 et seq.

67 Gregory, Callus on my Soul, p. 112.
} 
cafe in Chicago in 1958, and authored several books on how to attain health and longevity through a regimented "natural" diet which included raw and wholefoods, vegetarianism, and fasting. She also edited Gregory's cookbook. ${ }^{68}$ Gregory's enthusiasm for the practices taught to him by Fulton, and especially their results in terms of his weight loss, health, and general wellbeing, soon eclipsed the ethical component in his public promotion of dietary reform. His outreach was focused on the African American community who already at that time were struggling with disproportionate health problems, many of which were diet-related. Gregory even designed a product called Formula Four $\mathrm{X}$ which contained a blend of vitamins and minerals, and was used by several sports and entertainment celebrities with positive results. ${ }^{69}$

Elijah Muhammad's dietary advice was only one part of a regime which demanded discipline in the fields of dress, sexuality, language, work, and economics, and it received no less attention from him. While dietary guidelines had been a part of the NOI since the leadership of W.D. Fard, these guidelines evolved up until at least the 196 os. $^{70}$

From 1965, Muhammad published a series of articles on correct dietary practice, many of which were compiled in How to Eat to Live (1968). These expanded greatly on the Quranic ideas regarding diet; strict instructions are given regarding all different food types, but the aim is always quite clear: how to eat to live rather than to die. The advice is extensive and at times seemingly arbitrary: Muhammad bans nuts, several kinds of beans, kale, sweet potatoes and white potatoes and fried food, allowing only one meal per day at the most (less is preferable). ${ }^{71}$

Most interesting is the advice regarding meat: pig is banned outright, but so is most chicken, ${ }^{72}$ and any bird that has left the nest; the hierarchy of meats has

68 Gregory, Natural Diet.

69 Semmes, Entrepreneur of Health, p. 546.

70 Holbrook, Radical Food, p. 200; Berg, Elijah Muhammad, esp. pp. 93-95. Holbrook shows that the NoI drew inspiration from the dietary reforms of the Seventh Day Adventists, who had been aggressively promoting health-based eating which included vegetarianism since the mid-19th century, adopting an ethical vegetarian approach in 1894 (Calvert, Eden's Diet; Numbers, Ellen White). More research is required but the connection here with the semi-Judaising Adventists' health, money, and sexuality-based approach to diet which also included kosher restrictions, twice daily eating (rather than once), and outright ban on tobacco and alcohol are intriguing, both in terms of the NOI and the AHIJ.

71 Muhammad, How to Eat to Live I, p. 63. This advice is mirrored in the 18-page list of permitted and prohibited foods given out in the Chicago Temple in the late 1950s which banned many kinds of bean along with collard greens and other cabbages; but most vegetables were permitted and even esteemed. Red meat was permitted but advised against.

72 Muhammad, How to Eat to Live I, p. 11. 
lamb at the top, beef is permissible in limited quantities, and that from kosher stores is best. However, Muhammad explicitly states that a vegetarian diet is preferable, and the less meat consumed the better. ${ }^{73}$ From this advice several followers did adopt a vegetarian $\operatorname{diet}^{74}$

Muhammad states the reason clearly: Any kind of meat, due to the difficulty in digesting it, shortens the lives of those who consume it. ${ }^{75}$ At no point are concerns for animals raised; solely the effect of eating upon the individual is of interest. His disgust for meat often seems to be a barely disguised disgust at animals, and special ire is reserved for the pig, which "was made for medical purposes - not a food for the people [...] this animal destroys the beautiful appearance of its eaters [...]. He is the foulest animal [...]. He is so poisonous that you can hardly poison him with other poison"; 76 "He is the ugliest and silliest-acting animal you have ever looked upon"; 77 "He is the ugliest, most stinking animal. With his ugly, muddy, reddish eyes, his ugly mouth and his ugly ears, he is just ugly."78 However, the correct diet can extend the lifespan "indefinitely." ${ }^{\text {"9 }}$ Unlike Ben Ammi, he includes dairy products in this category, though not raw foods which are considered unsuitable for human digestion. ${ }^{80}$

There are some strong similarities here with Ben Ammi: Specifically, the extension of lifespan, and the focus on the physical effects of eating meat. Particularly interesting is a passage where, recalling Ben Ammi's argument regarding the makeup of the body and the soil, Muhammad writes that, "Our bodies are made of the earth and contain a little of every matter of the earth's chemicals, stone, gold and silver."81 However, he is not as firm as Ben Ammi; he allows for the eating of meat, embodying a position more akin to some Jewish interpreters mentioned above when he writes, "Animal flesh? NO. But we are not committing a sin by eating animal flesh if we cannot help ourselves." ${ }^{2}$

73 Muhammad, How to Eat to Live II, p. 64. "By nature, the human body was not made to digest meats. Meat causes a great shortening of our lives. We all eat meat. I eat meat also, but it certainly is not good for us." (Muhammad, How to Eat to Live I, p. 116)

74 Curtis, Black Muslim Religion in the Nation of Islam, p. 108; White, Inside the Nation of Islam, p. 66.

75 Muhammad, How to Eat to Live I, pp. 63, 116.

76 Muhammad, How to Eat to Live I, p. 14.

77 Muhammad, How to Eat to Live I, p. 32.

78 Muhammad, How to Eat to Live I, p. 44.

79 Muhammad, How to Eat to Live I, p. 27.

8o Muhammad, How to Eat to Live I, p. 36. Curiously, despite singing the praises of milk, he also states it is stolen from calves to give to baby humans (p. 81).

81 Muhammad, How to Eat to Live II, p. 63.

82 Muhammad, How to Eat to Live II, p. 134. 
For many AAs in the 1960 s, the shift to a vegetarian diet was a negative change, one which actively defied one's roots: Soul Food was a hotly contested issue in the 196os. This southern, highly spiced, fatty and salty style of cooking that was developed to make best use of the kinds of foods available to slaves, was commonly viewed as an important part of black culture and rejection of it could be akin to rejection of one's own roots (it has formed an important part of, in Wallach's phrase, "culinary nationalism"); yet, it has become increasingly obvious that it is partially responsible for the kind of health problems which (still) plague black Americans, and for this reason has been heavily critiqued by some in the pursuance of health, wellbeing, and longevity for African Americans. ${ }^{83}$ Muhammad was among the strongest critics, proclaiming the now-traditional diet of African Americans as one of precisely the worst foods, which was deliberately inculcated into them as a means of destabilising and degrading a holy people:

They [whites] have taught the world of man to eat as they eat, their medical scientists have learned that meat hastens and destroys the life of man. But, they practice eating the very worst meat (the poisonous and filthy swine, wild birds, wild fowl of any kind, and even reptiles) and teach man to eat it. To follow them in everything they eat and drink means that you are absolutely inviting death. ${ }^{84}$

Gregory shares Muhammad's criticisms of soul food: the culinary style developed by slaves in the American South is lambasted as "Nothing but garbage",85 and a form of "genocide"; 86 but Ammi is even closer when he scathingly writes that "[t]he slaves were meticulously fed, like animals in hog troughs, a diet fit to keep and nourish only evil. They were fed the scum of the earth. The mainstay of their diet was a beast (swine), which God had commanded that they not eat, or for that matter, not even touch its carcass." 87 For Ammi the persistence of the diet among black Americans is part of their ongoing enthrallment

83 Wallach, How to Eat to Live; Covey/Eisnach, What the Slaves Ate. For contemporary critiques of Soul Food from a Black vegan perspective, see Ko/Ko, Aphro-ism.

84 Muhammad, How to Eat to Live I, p. 48 et seq.

85 Quoted in Vernon Jarrett, Dick.

86 "I personally would say that the quickest way to wipe out a group of people is to put them on a soul food diet. One of the tragedies is that the very folks in the black community who are most sophisticated in terms of the political realities in this country are nonetheless advocates of 'soul food.' They will lay down a heavy rap on genocide in America with regard to black folks, then walk into a soul food restaurant and help the genocide along." (Dick, Natural, p. 81)

87 Ammi, God, the Black Man \& Truth, p. 147. 
to the state of enslavement, where they "were purposely raised on nutritionally poor diets." 88

Soul Food then is unhealthy, demeaning, and unrighteous. However, like Ammi, Muhammad is not solely mechanical, he also posits that there is a psychological element to health: those who followed his directives precisely but still fell ill suffered "due to wrong mental food that they are eating, which has an effect on their digestive system. To get good results from eating the proper foods, we must have good thoughts." 89

It seems fair to say that the African American approach to plant-based eating has been more pragmatic in nature than the Jewish. That is to say, where the Jewish approach has until the 2oth century been almost entirely ethical and eschatological (and in the second half of the 2oth century the change was one of practical application not ideology), the AA thinkers exploring plantbased diets during the 2oth century made immediate decisive changes to their diet; but the reason for these changes was, even in the public narrative of Dick Gregory, primarily centred around health, and specifically the health of African-Americans.

The emphasis on health is shared by Ben Ammi, for whom the ethics of eating are largely confined to the effects upon oneself. This emphasis should not be taken lightly, nor should it be seen as a selfish outlook: AA communities in the 2oth century were in dire need of health advice and support. ${ }^{90}$ The issue of food justice is still live, as impoverished communities tend to have less access to healthy food than do the well-off, causing a downwards spiral which impacts not only longevity but also day-to-day quality of life and magnifies the problem of unequal access to healthcare. As Karl Evanszz writes, the dietary regime and healthy appearance of the Nation of Islam (NOI) was appealing to blacks in the 196os because "[i]n economically depressed areas where dental and health insurance were rare, home remedies and prayer were often the only answers to a health crisis." ${ }^{\prime 1}$ Ben Ammi's utilisation of scientific findings to support his prophetically and scripturally inspired adjustments is also prefigured in Muhammad's regulations, Holbrook describing his food program as "an amalgamation of American nutrition science, traditional Muslim law, and

88 Ammi, God, the Black Man \& Truth, p. 78 et seq. This is one area where the community narrative seems to differ from Ben Ammi's written opinion. The community's restaurants and even their own dining hall sought to mimic Soul Food staples in order to make vegan food palatable to those unused to it; a practice also carried out by the NOI as shown by Holbrook, Radical Food, p. 48.

89 Muhammad, How to Eat to Live II, p. 11.

90 See e.g. Witt, Black Hunger.

91 Evanszz, The Messenger, p. 347. 
prophecy."92 Indeed, the concern with health can be seen equally in the contemporaneous Harlem Black Jewish group The Commandment Keepers whose concern with kosher eating was "in a major respect part of an extraordinary preoccupation with disease, physical and mental," which expressed itself in a conviction that because of their ignorance and poverty "all their life they had been eating poison. ${ }^{\prime 93}$

The use of diet as a means of self-control is another important factor. We can see this also when Elijah Muhammad claims that a correct diet is solely an AA priority; he is happy for the white to "eat all the hog he wants", but it is imperative for AAs to save themselves. ${ }^{94}$ Essentially, this is an expression of the need to reassert control over the black body, which was for so long controlled by others. ${ }^{95}$ This renewed control must be asserted deliberately in reaction to the subtly induced post-slavery effects present in America, and thus the "freedoms" that AAs have to consume whatever they want must be (voluntarily) rescinded in order to 1) forge internal discipline and 2) remove the inculcated desire to consume substances that are harmful. There may also be an aspect of demonstrating the falsity of racist American stereotypes of Blacks as brutish and unrefined: the ability to exert self-control over one's consumption shows a sophisticated preference for rationality over immediate satisfaction. ${ }^{96}$ Similarly, Markowitz and Avieli have argued that the AHIJ's veganism is a core part of their re-scripting of heteronormative masculinity within strong family and community bases. As they note, this is in contrast to the common outlook of male vegans, who more frequently attempt to revise and overturn traditional notions of masculinity; however, Markowitz and Avieli perceived that the decoupling of masculinity from ideals of physical strength (and its corollary of violence) was an important aspect of detaching male members from American stereotypes, particularly of Blacks. Thus they succeeded in decoupling traditional responsibility and family-based maleness from a toxic aspect of hyper-masculinity. This still did not devalue health; in fact, the opposite. It seems then that the dietary reformation of the AHIJ owes significant debt

$92 \quad$ Holbrook, Radical Food, p. 28.

93 Brotz, BlackJews, p. 28.

94 For the emphasis on this for women, especially in terms of weight control, as well as the conditions which helped produce it, see Taylor, Promise of Patriarchy, pp. 54-79.

95 Potorti, Culinary Nationalism.

96 Muhammad's reforms "contradicted portrayals of African Americans as bestial and replaced them with the ideal that they descended from the ancient people of Shabbaz, who modeled self-restraint, rational thinking, and human flourishing." (Holbrook, Radical Food, p. 26). 
to that of Muhammad's NOI, in terms of its intent and its articulation, and it seems likely that the AHIJ was partly influenced by Muhammad's approach. ${ }^{97}$

Specific dietary practices have usually been seen as a means of boundary creation and maintenance; the Ancient Israelites forming a common exemplar. ${ }^{98}$ However, Holbrook has argued that boundary maintenance was not a critical motivating factor for NOI (or Mormon) food prohibitions. In fact, they both made the boundary as fluid as possible in order to increase the attraction to new members. The same is even more the case with the AHIJ they actively sought, from the outset, to spread their dietary ideals to the broader society in which they lived, indeed to all humans. The establishing of public eateries demonstrate that not only are they interested in recruiting new members, but that they even hope non-members will be influenced by their practices. The diet was not necessarily boundary enforcing (at least not in the way that biblical and rabbinic kashrut was): whereas kashrut makes sharing outsiders' food near impossible, AHIJ's rules were not difficult for others to accommodate. They were articulated in such a way as to enforce a definite change and an awareness of difference, but not to create an uncrossable division; AHIJ, like NOI, wanted to attract new members and in fact the dietary reforms have served as an important part of that; the diets, the health and selfcontrol they elucidate, are part of the attraction of the groups rather than a terrifyingly unfamiliar practice. This again places the AHIJ more in line with contemporaneous AA trends than with rabbinic Jewish ones which (at least in orthodox communities) continue the trend of separation.

For AHIJ and NOI the new diet is also tied to their immanent beliefs and the renewal of health as part of a holistic lifestyle. Both Ben Ammi and Elijah Muhammad rejected any notion of an afterlife, preferring to focus on the perfection and the extension of the one life we know. ${ }^{99}$ This "profoundly life affirming" 100 belief brings the concept of heaven into the reach of the present: heaven is not something postponed until after death as a reward, but attainable here and now as the natural consequence of living well.

The soul food traditions which may actively harm Black Americans have been a particular focus of criticism by all thinkers mentioned of African American heritage. ${ }^{101}$ This rejection in principle (although not completely

97 Both groups also disallow any intoxicating substances.

98 E.g., Douglas, Purity and Danger.

99 E.g., Muhammad, How to Eat to Live 1, p. 19.

100 Holbrook, Radical Food, p. 188.

101 It is interesting that, related to this is a frequent argument that meat-free diets are more natural; in fact, this is likely the case as West African tribes, though certainly not vegetarian in the contemporary sense, generally ate little meat, though with some seafood. Covey/Eisnach, What the Slaves Ate pp. 41-44. 
carried through in practice) also helped to signify the AHIJ and NOI's break with the demonised past, facilitating the assertion of a new identity. Singer has argued that the symbolic imaginary of the AHIJ allows members to "formulate personal restitutive narratives and thereby to take on a new identity that is free of the damaging effects of feeling like a failure and the weight of self-blame."102 The adoption of a radical new diet which is backed up with a cohesive, theologically grounded theory, makes the shift of self-understanding palpable, and one that is less likely to be withdrawn from. The personal importance of veganism to many members replicates the significance of the diet in the community's publicity: it is a core part of their identity. One member, who was born into the community but left for some years, told me they had tried everything that was disallowed except animal products and tobacco, thereby suggesting that the perception of such foods that the community inculcates is not one of simply being off-limits, but of not being food; the member did not perceive them as something to be indulged in once free of the community's rules. This makes the AHIJ's veganism far more significant than the NOI's dietary rules which are at most a guideline, part of what one member calls the NoI's "selfesteem program"; 103 breaking them earned at most a Class $C$ punishment, and this only when traditionally non-halal products such as pork or alcohol were consumed. In contrast, the AHIJ interpret their dietary regulations as biblical, on a par with all other God-given commandments and directly relate them to the expulsion from Eden and subsequent process of descent.

One last area where NOI and AHIJ ideals meet is self-sufficiency. From the outset the AHIJ hoped to attain autonomy by growing their own food, establishing a camp farm in Liberia and later an "urban kibbutz" in Israel. Muhammad sought to establish NOI farms which would produce high quality foods by and for members of the Nation. ${ }^{104}$

The one area where AHIJ diverge from NOI is in their use of scripture; Muhammad's reforms were almost entirely not based on the Qu'ran or the Bible except for in his distaste for pig. Ammi in contrast constantly returns to biblical passages and allusions in order to solidify his ideas.

Finally, we must address the question of direct influence. Gregory has not been mentioned by anyone in the community, but Fulton was named by Gavriel haGadol as an influential figure on the Chicago group's diet even before they left America. ${ }^{105}$ There was a keen mutual interest between them

\footnotetext{
102 Singer, Identity Formation, p. 63.

103 Holbrook, Radical Food, p. 205.

104 Holbrook, Radical Food, pp. 71-116; McCutcheon, Returning Home.

105 HaGadol/Israel, The Impregnable People, p. 76.
} 
and Muhammad's NoI, as demonstrated by the April 1974 open letter they wrote to Muhammad and the mentions given to them in Muhammad Speaks.

\section{$5 \quad$ Conclusions}

Many in the 196os counterculture(s) saw diet as a means of opposition to mainstream ideology, and a variety of practices were adopted to express this non-conformism. Ben Ammi and the AHIJ are far from alone in this and their dietary reforms clearly drew upon a trend which was already present within American society. The preceding analysis has shown that the ultimate source may well have been the NOI and other 2oth century Black American figures. However, Ammi's principle motivator is the biblical text, and he found within it the same attitude toward meat as did the rabbis, with whom he shares the idea of the singular importance of scripture as inspiration and ultimate arbiter in correct behaviour. Like Kook, Abarvanel, and many others, Ammi perceived a distinct distaste for meat in the Hebrew Bible. While there is no evidence of direct influence from rabbinic sources, he is implicitly dependent on the same scriptural references as them: Gen. 1:29 and Is. 65. However, where the rabbis foregrounded ethics, Ammi shared Fulton, Gregory, and Muhammad's emphasis on health. In addition, Kook and Ammi have in common their location of compassion for animals within a grand framework of holistic ethics and concern for the natural world in all its parts; indeed, for no thinker cited herein except perhaps Gregory, are animal rights the foundation of their reforms. But a compassionate and non-violent approach to animals and eating forms part of a grander compassionate worldview for almost all.

This study supports Baer/Singer's claim that their diet is presented in terms of scripture while at the same time rejecting their claim that this is instead of health; both are crucially important, and both have been utilised by the community in explaining their reforms. ${ }^{106}$ It also supports Dorman's argument that the broad movement of Black Israelism is essentially bricoleur in nature. Ben Ammi and the AHIJ decided which parts of different traditions and sources to emphasise and combined them into a new whole; Ammi's impressively systematic thought makes veganism an integral part of righteous living in the present age, an essential ingredient in overturning the millennia of error and fulfilling humanity's true potential: immortal life.

What stands as unique is that Ammi's new revelation was successful in imposing a completely vegan diet upon the entire community, in contrast to the relative disappearance of Gregory's Formula Four X, and the only partial

106 Baer/Singer, African American Religion in the Twentieth Century, p. 276. 
uptake of vegetarianism within the NOI and rabbinic or secular Judaism. The reason for this must, I believe, be found in his ability to ground the diet in sacred scripture while also arguing that it is an imperative upon the specific community of believers. Ben Ammi utilised biblical traditions, long known and used similarly by rabbinic authorities, to assert that the intended and ideal diet for humans was veganism, that meat was only sanctioned dependent upon humanity's corruption, and that in the messianic age we would return again to this preferred diet. These passages have inspired previous generations of Jewish thinkers without leading to their adoption of a plant-based diet. Ben Ammi brought this ideology into the present moment as part of his theology that the messianic age had arrived, and the Kingdom of Yah was in the process of establishing itself upon the earth.

\section{Acknowledgements}

The author is grateful to the journal editors and reviewers for their advice; to Ahmahlyah for providing information and interview participants; to Jacob A. Labendz of Youngstown State University for reading the first draft; to staff at the Schomburg Center for Research in Black Culture for providing scans of archive material; and to Jacob Adler (University of Arkansas) for providing a scan of one article in Israel magazine.

\section{Biography}

Dr Michael T. Miller works in Jewish Studies, specialising in Jewish mysticism and philosophy, and more recently, Black Judaism. His first monograph, The Name of God inJewish Thought was published by Routledge 2016. He is currently a Gerda Henkel fellow working at the Polish Institute of Advanced Studies where he pursues research into the African Hebrew Israelite community.

\section{Bibliography}

Ammi, Ben: God, the Black Man, and Truth. Washington, DC: Communicators Press (second revised edition) 1990.

Ammi, Ben: God and the Law of Relativity. Washington, DC: Communicators Press 1991. Ammi, Ben: The Messiah and the End of This World. Washington, DC: Communicators Press 1991. 
Ammi, Ben: Everlasting Life: From Thought to Reality. Washington, DC: Communicators Press 1994.

Ammi, Ben: The Global Crisis: The End Result of Applied Knowledge, Washington DC 2002, https://www.youtube.com/watch?v=iMXtlQmKT3w\&t=1s (date of last access: 29.12.2020).

Ammi, Ben:Physical Immortality: Conquering Death. Washington, DC:Communicators Press 2010.

Associated Press: Judaist Negroes Drift Toward Israel After Fleeing America, in: The Daily Dispatch (Moline, Illinois), 11.10.1969, p. 6.

Avieli, Nir/Markowitz, Fran: Slavery Food, Soul Food, Salvation Food: Veganism and Identity in the African Hebrew Israelite Community, in: African and Black Diaspora: An International Journal 11 (2/2018), pp. 205-220.

Baer, Hans A./Singer, Merrill: African American Religion in the Twentieth Century: Varieties of Accommodation and Protest. Knoxville: University of Tennessee Press (second edition) 2002.

Baht Israel, Yadah: The Holistic Lifestyle. In: Hare (ed.): The Hebrew Israelite Community, pp. 9-26.

Belasco, Warren J.: Appetite for Change: How the Counterculture Took On the Food Industry, 1966-1988. New York: Pantheon 1989.

Berg, Herbert: Elijah Muhammad and Islam. London: New York University Press 2009.

Berger, Graenum: Black Jews in America: A Documentary with Commentary. New York: Commission on Synagogue Relations 1978.

Brotz, Howard: The Black Jews of Harlem: Negro Nationalism and the Dilemmas of Negro Leadership. London: Macmillan 1964.

Calvert, Samantha Jane: Eden's Diet: Christianity and Vegetarianism 1809-20o9. PhD dissertation: University of Birmingham 2012.

Chandler, Sarah/Cohan, Jeffrey: Jewish Vegan and Vegetarian Movements in North America, in:Jewish Veganism and Vegetarianism: Studies and New Directions (ed. by Jacob Ari Labendz/Shmuly Yanklowitz). Albany: State University of New York Press 2019, pp. 341-36o.

Cohen, Alfred S.: Vegetarianism from a Jewish Perspective, in: Journal of Halachah and Contemporary Society 1 (2/1981), pp. 38-63.

Covey, Herbert C./Eisnach, Dwight: What the Slaves Ate: Recollections of African American Foods and Foodways from the Slave Narratives. Santa Barbara: Greenwood Press 2009.

Curtis IV, Edward: Black Muslim Religion in the Nation of Islam, 1960-1975. Chapel Hill: University of North Carolina Press 2006.

Dorman, Jacob S.: Chosen People: The Rise of American Black Israelite Religions. Oxford: Oxford University Press 2013. 
Douglas, Mary: Purity and Danger: An Analysis of Concepts of Pollution and Taboo. New York: Routledge \& K. Paul 1978.

Elkayam, Shelley: 'Food for Peace': The Vegan Religion of the African Hebrews of Jerusalem, in: Idea 26 (2014), pp. 317-40.

Elliott, Roberta: Interview with Ben Ammi, in: Newsview, 14.02.1984, p. 17.

Emerson, Gloria. U.S. Negroes Content as Israelites in Liberia, in: New York Times, o6.11.1968, p. 44.

Evanszz, Karl: The Messenger: The Rise and Fall of Elijah Muhammad. Westminster, MD: Pantheon Books 1999.

Finley, Stephen Carl: Re-imagining Race and Representation: The Black Body in the Nation of Islam. Unpublished $\mathrm{PhD}$ dissertation, Rice University 2009.

Funk, Cary/Kennedy, Brian: The New Food Fights: U.S. Public Divides Over Food Science. Pew Research Center 2016.

Gibeon, Shlomo: From Slavery in Chicago to Freedom in Dimona, in: Ma'ariv, 26.12.1969 [in Hebrew].

Greenstone, Victoria/Shmuel, Shlomi: A Linguistic Appraisal: Jewish Perceptions of Animal Suffering, in: Labendz/Yanklowitz (eds.):Jewish Veganism \& Vegetarianism, pp. $15^{8-184 .}$

Gregory, Dick: Dick Gregory's Natural Diet for Folks who eat; Cookin' with Mother Nature! (Ed. by James R. McGraw with Alvenia M. Fulton). New York. Harper \& Row 1973.

Gregory, Dick: Callus on my Soul: A Memoir. Atlanta: Long Street Press 2000.

HaGadol, Prince Gavriel/Israel, Odehyah B.: The Impregnable People: An Exodus of African Americans Back to Africa. Washington, DC: Communicators Press 1993.

Hare, A. Paul (ed.): The Hebrew Israelite Community. Lanham: University Press of America 1998.

Hare, A. Paul/Ben Yehuda, Immanuel/Baht Israel, Yadah: Emphasizing the Holy in Holistic Health Care, in: Hare (ed.): Hebrew Israelite Community, pp. 27-34.

Harper, A. Breeze (ed.): Sistah vegan: Black female vegans speak on food, identity, health, and society. New York: Lantern Books 2009.

Holbrook, Kate: Radical Food: Nation of Islam and Latter Day Saints Culinary Ideals (1930-80). PhD dissertation, Boston University 2014.

Jackson, John L., Jr.: Thin Description: Ethnography and the African Hebrew Israelites of Jerusalem. Cambridge, MA: Harvard University Press 2013.

Jerusalem Post: Cult's Critics Charge Secrecy, Strictness, and Brainwashing, in:Jerusalem Post, 22.01.1979.

Key, Andre E.: Toward a Typology of Black Hebrew Religious Thought and Practice, in: Journal of Africana Religions 2 (1/2014), pp. 31-66.

Ko, Aph/Ko, Syl: Aphro-ism: Essays on Pop Culture, Feminism, and Black Veganism from Two Sisters. New York: Lantern Books 2017. 
Kook, Rav Avraham Isaac: On Zionism, in: Hadvir 10 (12/1920): pp. 33-38 [in Hebrew]. Kook, Rav Avraham Isaac: A Vision of Vegetarianism and Peace: the Torah's Perspective (ed. by Rabbi David Cohen). Jerusalem: Nezer David 1983 [in Hebrew].

Könighofer, Martina: The New Ship of Zion: Dynamic Diaspora Dimensions of the African Hebrew Israelites of Jerusalem. Wein: Lit 2008.

Krinsky, Alan D.: Relevant and Irrelevant Distinctions: Speciesism, Judaism, and Veganism, in: Labendz/Yanklowitz (eds.): Jewish Veganism \& Vegetarianism, pp. 26o-276.

Labendz, Jacob Ari/Yanklowitz, Shmuly (eds.): Jewish Veganism and Vegetarianism: Studies and New Directions. Albany: State University of New York Press 2019.

Landing, James E.: BlackJudaism: Story of an American Movement. Durham: Carolina Academic Press 2002.

Lounds, Morris: Israel's Black Hebrews: Black Americans in Search of Identity. Washington DC: University Press of America 1981.

Ma'ariv: Ben-Ami and Hezekiahu Came From Liberia, in: Ma'ariv, o1.og.1968, p. 10 [in Hebrew].

Markowitz, Fran: Israel as Africa, Africa as Israel: "Divine Geography" in the Personal Narratives and Community Identity of the Black Hebrew Israelites, in: Anthropological Quarterly 69 (4/1996), pp. 193-205.

Markowitz, Fran/Avieli, Nir: Food for the body and soul: Veganism, righteous male bodies, and culinary redemption in the Kingdom of Yah, in: Ethnography (2020), https://doi.org/10.1177\%2F1466138120910183.

McCutcheon, Priscilla: Returning Home to Our Rightful Place: The Nation of Islam and Muhammad Farms, in: Geoforum 49 (2013), pp. 61-7o.

Michaeli, Ethan: Another Exodus: The Hebrew Israelites from Chicago to Dimona. In: Yvonne Chireau/Nathaniel Deutsch (eds): Black Zion: African American Religious Encounters with Judaism. New York: Oxford University Press 200o, pp. 73-9o.

Miller, Michael T.: Black Judaism(s) and the Hebrew Israelites, in: Religion Compass 13 (11/2019): E12346.

Miller, Michael T.: The African Hebrew Israelites of Jerusalem and Ben Ammi's Theology of Marginalisation and Reorientation, in: Religions 11 (2/2020), p. 87.

Muhammad, Elijah: How to Eat to Live I and II. Phoenix, AR: Secretarius MEMPS Publications 1972.

Muhammad, Elijah: The Supreme Wisdom Lessons by Master Fard Muhammad. Elijah Muhammad 1993.

Numbers, Ronald L.: Prophetess of Health: A Study of Ellen G. White. Grand Rapids, MI: Eerdmans (third edition) 2008.

Original Hebrew Israelite Nation: Journey of the Original Hebrew Israelite Nation of Jerusalem in Liberia, West Africa. Dimona. Original Hebrew Israelite Nation 1973. John Henrik Clark Papers, The Schomburg Center for Black Culture, box 41 folder 2. 
Original Hebrew Israelite Nation: Letter to Elijah Muhammad, o1.04.1974. John Henrik Clark Papers, The Schomburg Center for Black Culture, box 41 folder 2.

Potorti, Mary: Eat to Live: Culinary Nationalism and Black Capitalism in Elijah Muhammad's Nation of Islam. In: Dawn-Marie Gibson/Herbert Berg (eds.): New Perspectives on the Nation of Islam. New York: Routledge 2017, pp. 68-94.

Reuters: Israel: A Mecca for Vegans, https://www.ynetnews.com/articles/o,7340 ,L-4682589,oo.html (date of last access: 30.03.2021).

Rosen, Rabbi David: Vegetarianism: An Orthodox Jewish Perspective. In: Roberta Kalechofsky (ed.): Rabbis and Vegetarianism: An Evolving Tradition. Marblehead, MA: Micah Publications 1995.

Rosenblum, Doron: The Dibbuk in Dimona, in: Davar, 15.10.1971, pp. 11-13, 27 [in Hebrew].

Schwartz, Richard H.: Judaism and Vegetarianism. New York: Lantern Books 2001.

Schwartz, Richard H./Sears, David: The Vegetarian Teachings of Rav Kook. In: Labendz/ Yanklowitz (eds.):Jewish Veganism \& Vegetarianism, pp. 244-258.

Semmes, Clovis E.: Entrepreneur of Health: Dick Gregory, Black Consciousness, and the Human Potential Movement, in: Journal of African American Studies 16 (2012), pp. 537-549.

Shemesh, Yael: Vegetarian Ideology in Talmudic Literature and Traditional Biblical Exegesis, in: Review of Rabbinic Judaism 9 (2006), pp. 141-166.

Singer, Merrill Charles: Saints of the Kingdom: Group Emergence, Individual Affiliation, and Social Change Among the Black Hebrews of Israel. PhD dissertation, Salt Lake City, UT: University of Utah 1979.

Singer, Merrill: Symbolic Identity Formation in an African American Religious Sect: The Black Hebrew Israelites. In: Yvonne Chireau/Nathaniel Deutsch (eds.): Black Zion: African American Religious Encounters with Judaism. New York: Oxford University Press 2000, pp. 55-72.

Taylor, Ula Yvette: The Promise of Patriarchy: Women and the Nation of Islam. Chapel Hill: University of North Carolina Press 2017.

Vegetarian Resource Group: How Many Adult Vegetarians in the Us?, 2015, https://www .vrg.org/press/201511press.htm (date of last access: 29.12.2020).

Wallach, Jennifer Jensen: How to Eat to Live: Black Nationalism and the Post-1964 Culinary Turn, in: Study the South (2014), https://southernstudies.olemiss.edu/ study-the-south/how-to-eat-to-live/ (date of last access: 20.05.2021).

Weiss, Erica: 'There are no chickens in suicide vests': The Decoupling of Human Rights and Animal Rights in Israel, in: Journal of the Royal Anthropological Institute 22 (2016), pp. 688-706. 
White Junior, Vibert L.: Inside the Nation of Islam: A Historical and Personal Testimony by a Black Muslim. Gainesville: University Press of Florida 2001.

Whitfield, Thomas: From Night to Sunlight. Nashville, TN: Broadman Press 1980.

Wigoder, Devorah Emmet: America's Black Jews in Israel, in: Israel Magazine 3 (1970), pp. 34-43.

Witt, Doris: Black Hunger: Food and the Politics of U.S. Identity. New York: Oxford University Press 1999. 